\title{
Secondary production and diet of an invasive snail in freshwater wetlands: implications for resource utilization and competition
}

\author{
King Lun Kwong • David Dudgeon • \\ Pak Ki Wong · Jian-Wen Qiu
}

Received: 26 February 2009/Accepted: 21 July 2009/Published online: 4 August 2009

(C) Springer Science+Business Media B.V. 2009

\begin{abstract}
Invasive species can monopolize resources and thus dominate ecosystem production. In this study we estimated secondary production and diet of four populations of Pomacea canaliculata, a freshwater invasive snail, in wetlands (abandoned paddy, oxbow pond, drainage channel, and river meander) in monsoonal Hong Kong (lat. $22^{\circ} \mathrm{N}$ ). Apple snail secondary production (ash-free dry mass [AFDM]) ranged from 165.9 to $233.3 \mathrm{~g} \mathrm{~m}^{-2}$ year $^{-1}$, and varied between seasons. Production was lower during the cool dry northeast monsoon, when water temperatures might have limited growth, but fast growth and recruitment of multiple cohorts were possible throughout much (7-10 months) of the year and especially during the warm, wet southwest monsoon. The diet, as revealed by stomach-content analysis, consisted mainly of detritus and macrophytes, and was broadly consistent among habitats despite considerable variation in the composition and cover of aquatic plants. Apple snail annual production was $>10$ times greater than production estimates for other benthic macroinvertebrates in Hong Kong (range 0.004-15 g AFDM m ${ }^{-2}$ year $^{-1}$,
\end{abstract}

K. L. Kwong · P. K. Wong · J.-W. Qiu ( $₫)$

Department of Biology, Hong Kong Baptist University,

Hong Kong SAR, China

e-mail: qiujw@hkbu.edu.hk

D. Dudgeon

Division of Ecology and Biodiversity, School of Biological Sciences, The University of Hong Kong, Hong Kong SAR, China $n=29)$. Furthermore, annual production estimates for three apple snail populations (i.e. $>230 \mathrm{~g}$ AFDM $\mathrm{m}^{-2}$ year $^{-1}$ ) were greater than published estimates for any other freshwater snails (range 0.002-194 g AFDM m ${ }^{-2}$ year $^{-1}, n=33$ ), regardless of climatic regime or habitat type. High production by $P$. canaliculata in Hong Kong was attributable to the topical climate (annual mean $\sim 24^{\circ} \mathrm{C}$ ), permitting rapid growth and repeated reproduction, together with dietary flexibility including an ability to consume a range of macrophytes. If invasive $P$. canaliculata can monopolize food resources, its high productivity indicates potential for competition with other macroinvertebrate primary consumers. Manipulative experiments will be needed to quantify these impacts on biodiversity and ecosystem function in wetlands, combined with management strategies to prevent further range extension by $P$. canaliculata.

Keywords Apple snail - Biomass - Herbivory · Invasive species $\cdot$ Secondary production

\section{Introduction}

Threats to global freshwater biodiversity fall into five categories: overexploitation, water pollution, flow modification, destruction or degradation of habitat, and invasion by exotic species (Dudgeon et al. 2006). While these threats interact, and will likely be 
exacerbated by global climate change, attempts at mitigation will require estimation of their relative importance. Increases in trade and social and recreational exchanges associated with globalization over the last few decades have facilitated biological invasions that have had profound economic and ecological consequences (Vitousek et al. 1997; McNeely 2001; Lodge and Shrader-Frechette 2003). In a recent analysis of the extinction of 170 animal species, where causative factors were known, $54 \%$ (91 cases) included the effects of invasive species and for $20 \%$ of cases invasive species were the only cited cause of extinction (Clavero and García-Berthou 2005). Furthermore, the impacts of invasive species on biodiversity are likely to be relatively more important for freshwater ecosystems (especially lakes) than for terrestrial ecosystems because of both extensive intentional releases (e.g. fish stocking) and unintentional introductions of organisms (Sala et al. 2000; Vitule et al. 2009). Existing data support this prediction: the detrimental effects of invasive or introduced species have been cited as a causative factor in $68 \%$ of fish extinctions in North America (Miller et al. 1989). Ecosystem-level consequences or serious nuisance effects have been reported for many invasive exotic freshwater organisms (see Lowe et al. 2000; Vitule et al. 2009), including species such as Nile perch (Lates niloticus), mosquito fish (Gambusia affinis), walking catfish (Clarias batrachus), tilapias, water hyacinth (Eichhornia crassipes), floating fern (Salvinia molesta), Chinese mitten crab (Eriocheir sinensis), Asian clams (Corbicula fluminea), zebra mussel (Dreissena polymorpha), golden mussel (Limnoperna fortunei), and a number of freshwater snails. Among this last group, apple snails, particularly Pomacea spp. (Ampullariidae), are pre-eminent.

Pomacea spp. are native to South and Central America, and at least two species (Pomacea canaliculata and Pomacea insularum) have been introduced from Argentina and Brazil and have subsequently become invasive (Naylor 1996; Cowie 2002; Estebenet and Martín 2002; Hayes et al. 2008). P. canaliculata became established in Asia during the 1980s, and causes huge economic losses in some countries by devouring rice and other irrigated crops (Naylor 1996; Cowie 2002; Joshi and Sebastian 2006). Apple snails also consume native macrophytes thereby altering nutrient cycling and algal production in invaded wetlands (Carlsson et al. 2004; Carlsson and Lacoursière 2005). In Hong Kong, it has spread to occupy most low-lying $(<100 \mathrm{~m}$ asl $)$ wetlands, including streams, flooded agricultural land, marshes and fish ponds (Yipp et al. 1991; Dudgeon and Corlett 2004), although it does not thrive in habitats that have waters with low alkalinity or phosphate and is not found at sites where $\mathrm{Ca}^{2+}$ concentrations are $<9 \mathrm{mg} \mathrm{l}^{-1}$, such as some low order streams (Kwong et al. 2008). Pomacea spp. have high fecundity, fast growth, and dietary flexibility which, together with a lack of effective natural enemies in invaded wetlands, have been invoked to account for the success of these exotic snails (Cowie 2002; Estebenet and Martín 2002; Boland et al. 2008). This suite of attributes, together with superior competition for resources, allow other invasive species to threaten native molluscan biodiversity (Strayer 1999), presumably through pre-emptive consumption of available food resources. Estimates of secondary production could help confirm this assumption in apple snails and provide a good indicator of their potential impact. Secondary production reflects resource utilization and integrates life-history traits (Benke 1996) thereby indicating the role a species plays in energy flow and material processing in communities, and the possible consequences for native species (Hall et al. 2006).

There are no estimates of the secondary production of Pomacea spp. in the literature, although their densities and biomass have been reported to vary greatly with habitat (Cowie 2002; Wada et al. 2004). In the present study, we estimated production by $P$. canaliculata in four freshwater wetlands in Hong Kong, southern China. We expected macrophyte coverage to be an important determinant of apple snail production since plants constitute a major part of the diet (Cowie 2002). For this reason, we carried out stomach-content analyses of snails in each of the four study sites. Our objectives were to: (1) estimate the magnitude of secondary production by $P$. canaliculata, and estimate the extent of seasonal and interpopulation variation in production; and (2) compare production of invasive apple snails with production estimates for native freshwater macroinvertebrates in Hong Kong, and literature estimates for other invasive and non-invasive gastropods. 


\section{Methods}

Study sites and sampling

The study was carried out in Hong Kong Special Administrative Region (lat. $22^{\circ} 09^{\prime}-22^{\circ} 37^{\prime} \mathrm{N}$ ) which has tropical climate with two distinct seasons (Dudgeon and Corlett 2004): the wet season (AprilSeptember) and the dry season (October-March). The present study was undertaken from January to December 2007, when mean monthly air temperatures ranged from 16.4 (January 2007) to $29.6^{\circ} \mathrm{C}$ (July 2007); the overall mean for the study period was $23.7^{\circ} \mathrm{C}$ (Hong Kong Observatory 2009). Monthly rainfall ranged from $6.9 \mathrm{~mm}$ (February 2007) to $490.1 \mathrm{~mm}$ (June 2007), and totalled 1,706.9 mm; $92 \%$ of this fell during the wet season.

Two lentic and two lotic freshwater wetlands were selected to represent the variety and range of habitats occupied by in Hong Kong. Chau Tau Tsuen (CTT, $22^{\circ} 30^{\prime} 22.68^{\prime \prime} \mathrm{N}, 114^{\circ} 04^{\prime} 52.92^{\prime \prime} \mathrm{E}$ ) was a 1.2 -ha abandoned former rice paddy. $\mathrm{Ng}$ Tung Pond (NTP, $\left.22^{\circ} 30^{\prime} 54.50^{\prime \prime} \mathrm{N}, \quad 114^{\circ} 07^{\prime} 21.36^{\prime \prime} \mathrm{E}\right)$ was a 0.5 -ha oxbow pond. Tin Liu Ha (TLH, $22^{\circ} 27^{\prime} 2.88^{\prime \prime} \mathrm{N}$, $\left.114^{\circ} 08^{\prime} 35.34^{\prime \prime} \mathrm{E}\right)$ was a sandy-bottomed cement-lined channel $(40 \mathrm{~m}$ long $\times 1.5 \mathrm{~m}$ wide $\times 1.4 \mathrm{~m}$ high $)$ draining agricultural land (market gardens). The fourth site was a river meander in Long Valley (LV, $22^{\circ} 30^{\prime} 20.16^{\prime \prime} \mathrm{N}, 114^{\circ} 06^{\prime} 40.32^{\prime \prime} \mathrm{E}$. These sites differed in vegetative cover and composition, flow rate, water depth, and dissolved oxygen content, which could affect apple snail growth and reproduction.

Apple snail sampling was conducted monthly. On each occasion, two measurements of water depth and subsurface temperature were taken at the centre of each study site with a ruler and a digital thermometer. Six benthic samples were collected systematically along the longest axis of each site, with approximately equal distance between the 6 sampling locations. In instances where rooted macrophytes were scarce and visibility was good, a hand net (dimension: $25 \times 20 \mathrm{~cm}$, mesh size: $0.5 \mathrm{~mm}$ ) was used to scoop up the top $2 \mathrm{~cm}$ of sediment (plus snails) within a $0.5 \times 0.5 \mathrm{~m}$ quadrat. When the macrophytes were abundant or water clarity was low, a modified trapping method was used (Darby et al. 1999). The trap was an aluminium-framed PVC box $(0.5 \times 0.5 \times 0.5 \mathrm{~m})$ that lacked a top and bottom. A removable $0.5-\mathrm{m}$ extension was placed on the top of the trap, when necessary, to permit sampling in deeper water. Macrophytes inside the trap were uprooted and thoroughly rinsed in a net to remove snails, and the plants were brought back to the laboratory for further examination for the presence of snails. A hand net was used to sweep the bottom 20 times to collect snails and sediment, which was sufficient to remove all snails from the trap. Samples collected by both methods were taken to the laboratory, sieved (mesh size: $0.5 \mathrm{~mm}$ ) and the snails were picked out from the residues. For each snail, shell length (SL), defined as vertical distance from the apex to the basal extreme of the aperture, was measured to the nearest $0.01 \mathrm{~mm}$ with the aid of a stereomicroscope (for snails $\leq 5 \mathrm{~mm} \mathrm{SL}$ ) or digital Vernier calipers (for snails $>5 \mathrm{~mm} \mathrm{SL}$ ).

A separate sample of apple snails (91-115 individuals; SL 3.1-47.2 mm) was collected from each site in July 2007. The dry mass was determined after drying snails of known SL at $50^{\circ} \mathrm{C}$ for $48 \mathrm{~h}$ and weighing them to the nearest $0.01 \mathrm{~g}$. Ash free dry mass (AFDM) of each was determined after ignition of each snail at $550^{\circ} \mathrm{C}$ in a muffle furnace for $10 \mathrm{~h}$. A power function $\left(Y=a X^{b}\right)$ was employed to establish the relationship between SL and AFDM. Such a correlation was used to convert the shell length data from each month to biomass.

Density and biomass of apple snail populations at the four study populations during the dry and wet seasons was compared by 2-way analysis of variance (ANOVA) with site and season as factors using SPSS for Windows 11 followed by multiple comparisons of the site factor using Tukey tests.

Estimation of apple snail secondary production

Since not all cohorts could be followed from the field data, secondary production of $P$. canaliculata was estimated using the size-frequency method, which assumes that a mean size-frequency distribution determined from samples collected throughout 1 year approximates the size-frequency curve for an average cohort (Benke 1996). The change in biomass from one size class to the next was determined by multiplying the decreased density and the mean mass between the two size classes. The sum of biomass change for all size classes was multiplied by the total number of size classes to give the secondary production. This value was then corrected using cohort 
production interval (CPI, the time taken for an individual to grow from hatching to final size), based on observation of the size-frequency histograms that revealed the development of cohorts, to give the annual secondary production (Benke 1996).

Stomach content analysis

Samples were collected from each site in January and August 2007 to represent the diet in the dry and wet seasons, respectively. One each occasion, 8-11 adults of $P$. canaliculata $(25-35 \mathrm{~mm} \mathrm{SL})$ were collected haphazardly from each site. The shells were cracked and the snails were placed in 5\% neutralized formalin in the field to limit further digestion of the gut contents. Within 3 weeks of collection, each snail was dissected and the stomach contents dispersed in $10 \mathrm{ml}$ of distilled water. One milli litter of this suspension was transferred into a Sedgewick-Rafter counting cell and examined at $100 \times$ or $200 \times$ magnification under a compound microscope. For each counting cell, 100 of the 1,000 grids ( 20 rows $\times 50$ columns) were chosen (number 5 and 15 on each column) for examination, and presence of food items in each grid was scored (1 or 0 ). The process was repeated five times for every stomach to yield an average percentage score for each item in that individual. A sample of stomach contents from each snail were also mounted on glass slides and examined under $400 \times$ to confirm identification of dietary items. Snail food items were classified into 6 categories: amorphous detritus, macrophytes, cyanobacteria, diatoms, green algae, and invertebrate parts (i.e. whole or incomplete invertebrates). Sand grains were not counted as food items. Relative abundance data for the stomach contents were arcsine-transformed and analysed using PRIMER (Clark and Gorley 2006). Non-metric multidimensional scaling
(nMDS) was applied to ordinate stomach composition according to site and season using Bray-Curtis similarities, followed by 2-way crossed analysis of similarities (ANOSIM) to determine the significance of site and season effects, and similarity percentages procedure test (SIMPER) to determine the contributions made by each food type taxa to the overall difference.

\section{Results}

Population dynamics, production, and correlation with water temperature

Mean monthly snail density ranged from 25.6 to 42.7 indiv. $\mathrm{m}^{-2}$ (Table 1). Two-way ANOVA showed that there were significant differences in the density among sites (Table 2). The Tukey tests revealed that there were two homogenous subsets of sites ([LV, CTT, TLH] and [CTT, TLH, NTP]), indicating snail density at LV was significantly higher than that at NTP, but the densities at CTT and TLH were intermediate. Snail density showed a clear seasonal pattern (Table 1), with the wet season having a significant higher density than the dry season (Table 2). Despite intersite difference in snail density, the four populations showed a similar pattern of size distribution (Fig. 1). They were numerically dominated (site annual mean $54.6-62.6 \%$ ) by small juveniles ( $\leq 10 \mathrm{~mm} \mathrm{SL})$, followed by large juveniles 11-24 mm SL (31.2-37.1\%). Adult snails $\geq 25 \mathrm{~mm}$ SL were scarce $(5.5-8.2 \%)$. The largest snails attained $42 \mathrm{~mm}$ SL at CTT and LV, $45 \mathrm{~mm}$ SL at TLH, and $47 \mathrm{~mm} \mathrm{SL}$ at NTP. The smallest size classes $(\leq 3 \mathrm{~mm}$ SL) were present throughout much (7-10 months) of the year (CTT: March-October;

Table 1 Annual mean density $\pm \mathrm{SE}$, total annual biomass $(B)$, annual production $(P)$ and $P / B$ ratio in four populations of P. canaliculata

\begin{tabular}{|c|c|c|c|c|c|c|}
\hline \multirow[t]{2}{*}{ Population } & \multirow{2}{*}{$\begin{array}{l}\text { Density } \\
\text { (indiv. } \mathrm{m}^{-2} \text { ) }\end{array}$} & \multicolumn{3}{|c|}{ Biomass (g AFDM m ${ }^{-2}$ ) } & \multirow{2}{*}{$\begin{array}{l}\text { Production } \\
\left(\mathrm{g}_{\text {AFDM m}}^{-2} \text { year }^{-1}\right)\end{array}$} & \multirow[t]{2}{*}{$P / B$} \\
\hline & & $\begin{array}{l}\text { Dry season } \\
\text { (Oct-Mar) }\end{array}$ & $\begin{array}{l}\text { Wet season } \\
\text { (Apr-Sep) }\end{array}$ & Total & & \\
\hline Chau Tau Tseun (paddy) & $39.5 \pm 6.4$ & 4.62 & 21.23 & 25.86 & 233.3 & 9.40 \\
\hline Ng Tung Pond (pond) & $25.6 \pm 4.6$ & 4.32 & 17.95 & 22.27 & 165.9 & 7.45 \\
\hline Tin Liu Ha (channel) & $37.3 \pm 5.5$ & 7.82 & 26.22 & 34.04 & 312.7 & 9.15 \\
\hline Long Valley (meander) & $42.7 \pm 7.35$ & 8.57 & 24.66 & 33.23 & 299.4 & 9.19 \\
\hline
\end{tabular}


Table 2 Results of 2-way analysis of variance testing differences in apple snail density or biomass among four sites and between two seasons

\begin{tabular}{lrrr}
\hline Factor & $d f$ & \multicolumn{1}{l}{$F$} & \multicolumn{1}{l}{$P$} \\
\hline Density & & & \\
$\quad$ Site & 3 & 3.513 & $\mathbf{0 . 0 2 4}$ \\
Season & 1 & 59.960 & $<\mathbf{0 . 0 0 1}$ \\
Site $\times$ season & 3 & 0.766 & 0.520 \\
Error & 40 & & \\
Biomass & & & \\
Site & 3 & 1.481 & 0.234 \\
$\quad$ Season & 1 & 47.313 & $<\mathbf{0 . 0 0 1}$ \\
Site $\times$ season & 3 & 0.175 & 0.913 \\
Error & 40 & & \\
\hline
\end{tabular}

Statistically significant differences $(P<0.05)$ are shown in bold numbers
TNP: March-September, TLH: February-October; LV: March-December), indicating the occurrence of multiple cohorts.

A power function between SL $(\mathrm{mm})$ and biomass (mg) established for each population (CTT: $\mathrm{AFDM}=0.0083 \quad \mathrm{SL}^{3.1917}, n=107, r^{2}=0.989$; NTP: $\quad$ AFDM $=0.0115 \quad \mathrm{SL}^{3.0825}, \quad n=91, \quad r^{2}=$ 0.987; TLH: $\mathrm{AFDM}=0.01100 \mathrm{SL}^{3.1076}, n=115$, $r^{2}=0.987 ; \mathrm{LV}: \mathrm{AFDM}=0.0094 \mathrm{SL}^{3.1554}, n=91$, $r^{2}=0.988 ; P<0.001$ for all regressions) was used to convert SL data to biomass. Mean standing stocks were 2.9-4.6 times higher in the warmer wet season than in the dry season (Table 1). There were two temporal patterns: at TLH, monthly biomass remained high from May to September, but at the other three sites the peak occurred from June to August only (Fig. 2). Adults (50.2-58.8\%) and large

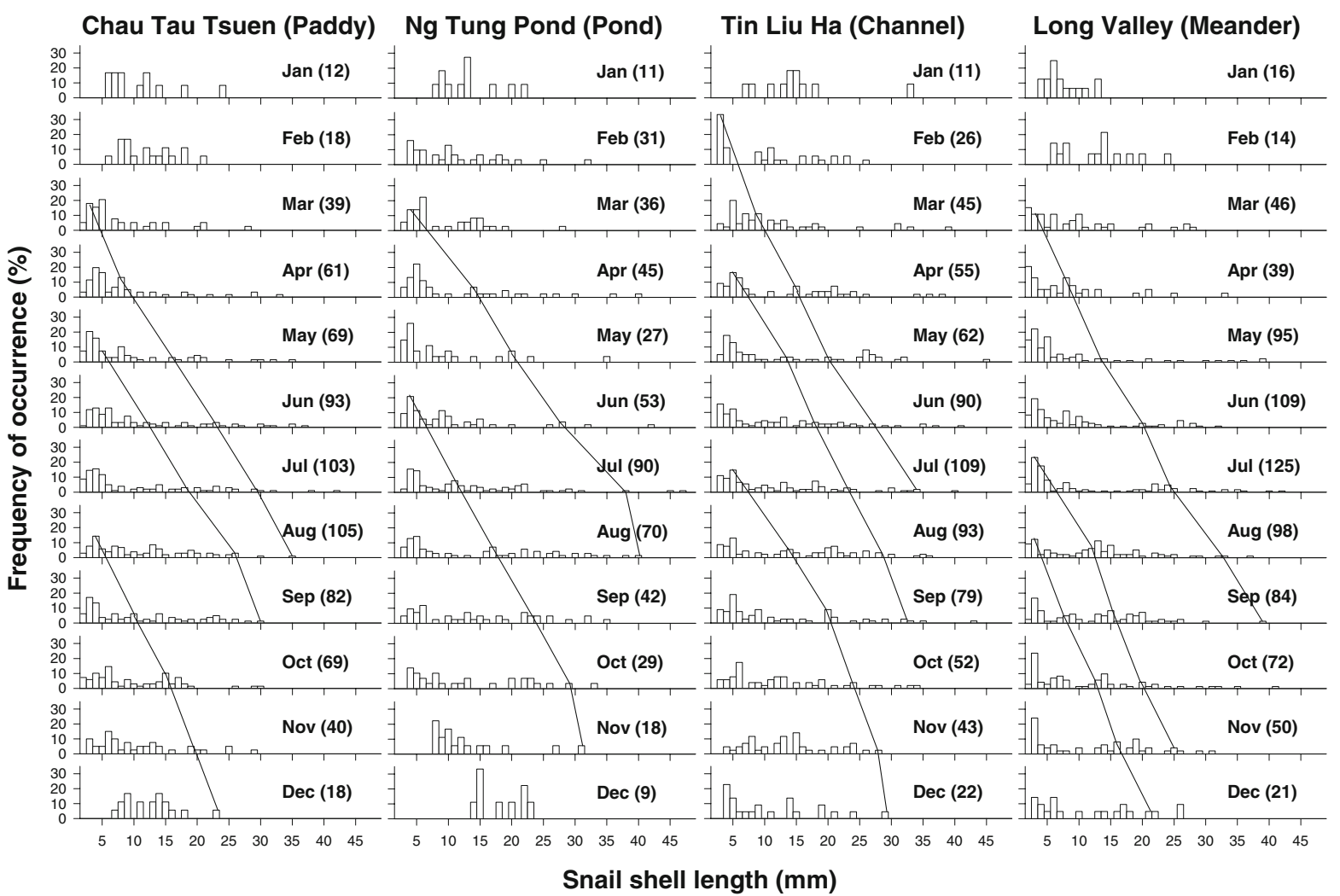

Fig. 1 Monthly size-frequency of 4 Pomacea canaliculata populations in Hong Kong wetlands sampled between January and December 2007. Data in parentheses are total number of snails collected. Lines connecting monthly histograms at each site are indicative examples of growth by representative cohorts 
Fig. 2 Biomass (g AFDM $\mathrm{m}^{-2}$ ) of 4 populations of Pomacea canaliculata in Hong Kong wetlands between January and December 2007. Changes in monthly mean water temperature are shown also

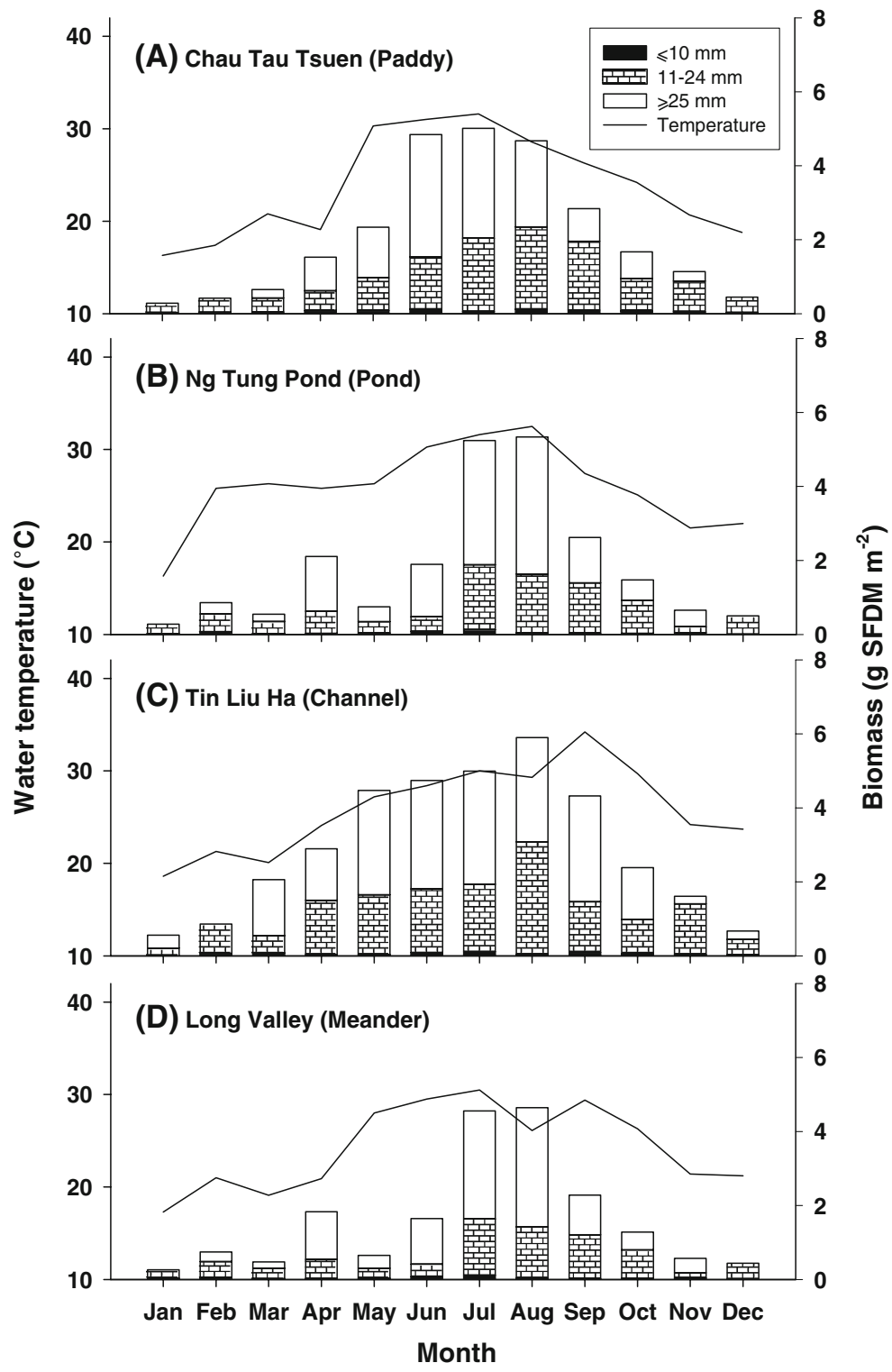

juveniles (38.7-46.6\%) were important contributors of the standing stock throughout the year. Small juveniles contributed to only a small fraction (2.0$3.3 \%$ ) of the population biomass.

Total annual snail biomass ranged from 22.3 to $34.0 \mathrm{~g} \mathrm{AFDM} \mathrm{m}^{-2}$ (Table 1). Two-way ANOVA showed that there were no significant differences in biomass among sites (Table 2). Snail biomass showed a clear seasonal pattern (Table 1), with the wet season having a significant higher biomass (1.9-3.6 times) than the dry season (Table 2). Examination of the growth of representative cohorts that could be traced from recruitment to final size indicated that the cohort specific interval (CPI) was 4-6 months (Fig. 1). When calculated using a conservative CPI of 6 months, snail production ranged from $165.9 \mathrm{~g} \mathrm{AFDM} \mathrm{m}^{-2}$ year $^{-1}$ at NTP to $312.7 \mathrm{~g} \mathrm{AFDM} \mathrm{m}^{-2}$ year $^{-1}$ at TLH, following the same sequence of site rankings by biomass (Table 1). The P/B ratio was high, but varied less markedly among populations than production, ranging from 7.5 year $^{-1}$ at NTP (which also had the lowest annual P) to 9.4 year $^{-1}$ at CTT.

Temporal changes in density and biomass reflected changes in water temperature. Linear correlation analyses revealed significant positive correlations between monthly snail standing stocks and water 
Fig. 3 Relative abundance (\%) of gut contents of Pomacea canaliculata in 4 sites and 2 seasons in Hong Kong. Detr. detritus, Mac. macrophytes, Cyan. cyanobacteria, Gre. green algae

Fig. 4 Non-metric multidimensional scaling solution for a 3-dimensional ordination of stomach composition of apple snails collected from four sites in two seasons. Different symbols (sea figure legend) represent snails from different sites. Filled and open symbols represent snails collected from the dry and wet season, respectively
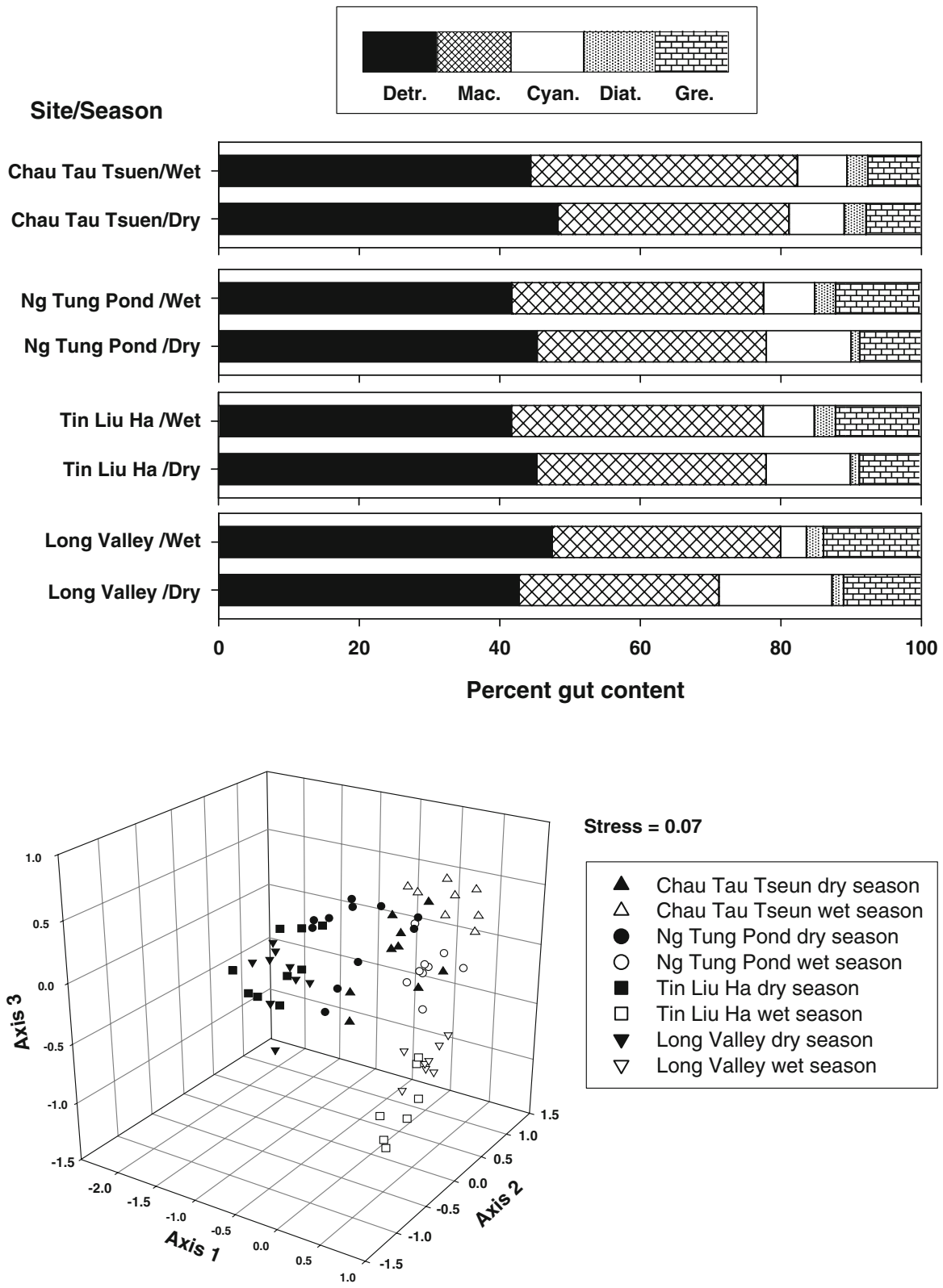

Stress $=0.07$ temperature at all of the 4 sites (biomass: $r^{2}=0.53-$ 0.82, $P<0.003$; density: $\left.r^{2}=0.62-0.81, P<0.002\right)$.

Snail stomach contents

The general composition of snail stomach contents was consistent across sites and between seasons (Fig. 3). Detritus had the highest frequency of occurrence (42-50\%), followed by macrophytes (28-38\%). Cyanobacteria, green algae, and diatoms were found consistently but at much lower density than detritus and macrophytes (cyanobacteria: 3-16\%, green algae: 8-14\%, diatoms: 1-3\%). Invertebrate body parts (i.e. microcrustacean appendages) were found only very infrequently (0-0.1\%).

Ordination of stomach contents gave a good representation (stress $=0.07$ ) of the data in a 3-dimensional nMDS plot (Fig. 4), which showed a clear separation of dry and wet season diets along Axis 1. The pattern of site separation appeared different in the two seasons: in the wet season, samples from the lentic sites (CTT and NTP) separated well from the 
lotic sites (TLH and LV) on the Axes 2 and 3; in the dry season, the two groups separated on Axis 1. Two-way ANOSIM revealed significant differences in stomach contents between seasons (Global $R=0.73$, $P=0.001)$. The overall differences across sites were also significant (Global $R=0.62, P=0.001$ ), as were all pairwise tests between sites $(P=0.001)$. However, the $R$ statistic for TLH versus LV and CTT versus NTP was only 0.36 and 0.38 , respectively, which indicated that the lentic sites and the lotic sites were not well separated, compared to LV versus CTT, LV versus NTP and TLH versus CTT ( $R$ statistic $=0.59-0.96)$. Nevertheless, results of SIMPER indicated that similarities between seasons (94-96\% across all site groups) and among sites (93-96\% across both season groups) were very high, with detritus and macrophytes together contributing to $76-84 \%$ of the overall similarity. Dissimilarities between seasons were low (10\% across all site groups), and with this dissimilarity contributed by cyanobacteria (35\%), detritus (22\%), macrophytes (19\%), green algae $(16 \%)$ and diatoms $(7 \%)$. Between-site dissimilarities were also low (7-12\% across both season groups), with contributions to total dissimilarity as follows: detritus (22-37\%), macrophytes (17-28\%), cyanobacteria (15-29\%), green algae (13-22\%) and diatoms (6-12\%).

\section{Discussion}

Secondary production of the $4 P$. canaliculata populations ranged from 165.9 to $312.7 \mathrm{~g} \mathrm{AFDM} \mathrm{m}^{-2}$ year $^{-1}$. To compare these values with other fresh water benthic invertebrates in Hong Kong, we compiled data from gastropods (Dudgeon 1986), aquatic insects (Jacobsen et al. 2008 [review]), and shrimps (Mantel and Dudgeon 2004; Yam and Dudgeon 2006; Fig. 5a). Production estimates from a total of 29 species ranged from $0.004 \mathrm{~g} \mathrm{AFDM} \mathrm{m}^{-2}$ year $^{-1}$ for the stream water beetle Psephenoides sp. (Psephenidae) to a maximum of $15.0 \mathrm{~g} \mathrm{AFDM} \mathrm{m}^{-2}$ year $^{-1}$ for the thiarid gastropod Melanoides tuberculata in flooded fields. However, even the highest production value is an order of magnitude less than the lowest value in the range of our estimates for $P$. canaliculata (165.9-312.7 $\mathrm{g} \mathrm{AFDM} \mathrm{m}^{-2}$ year $^{-1}$ ). We also compared our production estimates from Hong Kong

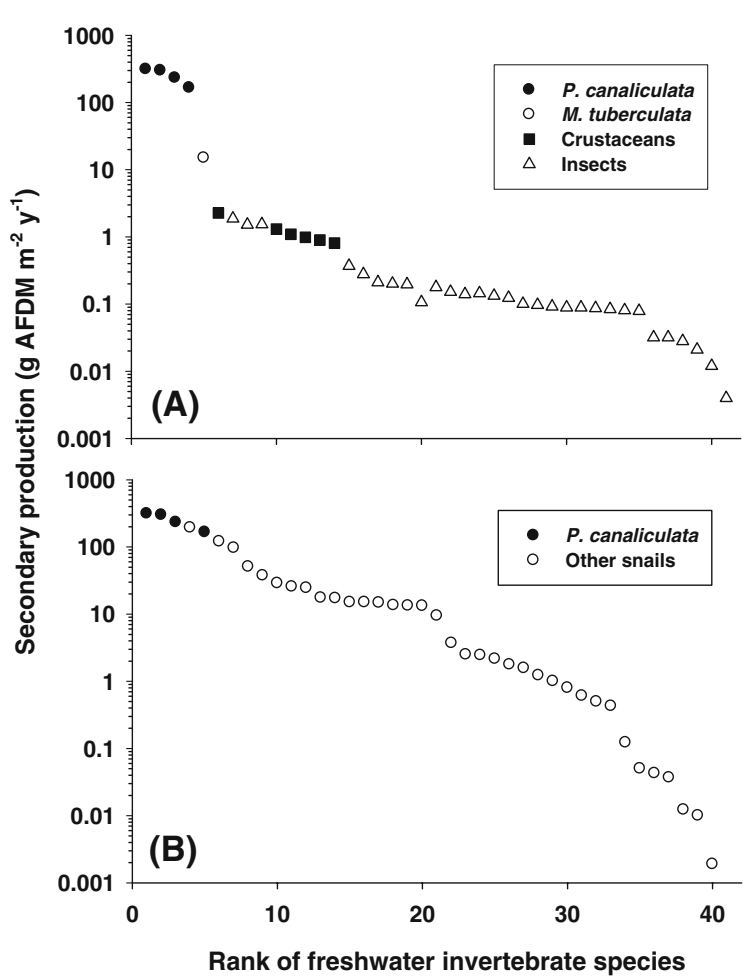

Fig. 5 Ranking of secondary production (g AFDM m ${ }^{-2}$ year $^{-1}$ ) of freshwater invertebrates. Unit conversion was conducted in some cases. For insects, a ratio of DM/AFDM = 1.2, based on the mean of 14 species (Dudgeon 1999), was used. For gastropods, ratios of SFDM/AFDM $=0.94$ and DM/ AFDM $=1.94$ (Kwong, unpublished data based on 33 individuals of $P$. canaliculata) were used. a Benthic invertebrates in Hong Kong. Data are from Dudgeon (1986), Mantel and Dudgeon (2004), Yam and Dudgeon (2006) and Jacobsen et al. (2008) (review). b Gastropods from around the world. Data are from Waters (1977) (review), Dudgeon (1986), Richardson et al. (1988), Richardson and Brown (1989), Bosnia et al. (1990), Eleutheriadis and Lazaridou-Dimitriadou (1995), Huryn et al. (1995), Gonzalez-Solis and Ruiz (1996), Yan et al. (2000), Eleutheriadis and Lazaridou-Dimitriadou (2001), Hall et al. (2001), Hall et al. (2006), and Chatterjee et al. (2008)

with values for 33 species of freshwater gastropods elsewhere (Fig. 5b). Values of $P$. canaliculata secondary production from Hong Kong ranked highly, regardless of region or habitat type, constituting 3 of the top 4 estimates, with the NTP estimate ranked 5th. The lowest production by any freshwater snail (0.002 $\mathrm{g} \mathrm{AFDM} \mathrm{m}^{-2}$ year $^{-1}$ or $<0.0013 \%$ of the estimates for $P$. canaliculata) was for Planorbis contortus (Planorbidae) in an English river (Waters 1977), whereas the highest value (194 g AFDM $\mathrm{m}^{-2}$ year $^{-1}$ ) was for invasive mud snail 
Potamopyrgus antipodarum (Hydrobiidae) in a Wyoming, USA river (Hall et al. 2006). These mud snails were small $\left(\sim 0.07 \mathrm{mg}\right.$ indiv. $\left.{ }^{-1}\right)$ but extremely abundant $\left(>500,000\right.$ indiv. $\left.\mathrm{m}^{-2}\right)$. Hall et al. (2006) attributed high productivity by $P$. antipodarum to high biomass and fast growth due to stable hydrology, availability of periphytic food, and warmer temperatures in Wyoming compared to its native range in New Zealand. In contrast to P. antipodarum, P. canaliculata were large (up to $47 \mathrm{~mm}$ SL and $1.7 \mathrm{~g}$ AFDM indiv. $^{-1}$ ) and had high biomass (22.3-34.0 $\mathrm{g}$ AFDM $\mathrm{m}^{-2}$ ), although density was low (7-83 indiv. $\mathrm{m}^{-2}$ ). Standing stocks of $P$. canaliculata were positively correlated with water temperature, supporting previous observations that temperature is an important determinant of the growth and reproduction in apple snails (Cowie 2002; Estebenet and Martín 2002). The lowest mean monthly temperature in Hong Kong during our study period was only $16.4^{\circ} \mathrm{C}$ (January 2007, Hong Kong Observatory 2009) and, although apple snails were inactive for 2-3 months (December-January or December-February), they did not hibernate. In southern Japan where the climate is colder, apple snails hibernate for 5 months (November-March) when water temperatures are $2-10^{\circ} \mathrm{C}$ (Sugiura and Wada 1999). The extended recruitment period (up to 10 months) and fast growth (close to $0.5-1 \mathrm{~cm}$ SL per month in the first 3 months) in Hong Kong must have contributed to the high productivity of $P$. canaliculata.

The stomach contents of $P$. canaliculata consistently contained five food types, supporting the assertion that it has a broad food spectrum (Estebenet 1995; Cowie 2002). Despite the changes in the amounts and types of macrophytes among sites and between seasons, the feeding strategy of $P$. canaliculata was flexible enough to ensure that the diet contained substantial amounts of detritus and macrophytes. In particular, this species was able to maintain 28-39\% macrophytes in its diet irrespective of seasonal changes in temperature, indicating that foraging for fresh macrophytes continued during the coldest periods. By contrast, macrophytes accounted for $<4 \%$ of food eaten by eight freshwater snails (not including P. canaliculata) in Hong Kong (Dudgeon and Yipp 1985); in a 9th species, the lymnaeid Radix plicatulus, macrophytes accounted for $<20 \%$ of the food eaten. Taken together, these studies indicate that the apple snail has a relatively broad food spectrum allowing them to effectively utilize food resources in various wetland habitats.

The apple snail production varied among sites by $\sim 2$ times. Although we cannot draw any conclusions about the factors responsible for this variation, our data appeared to indicate that macrophyte coverage was unimportant for snail production. For example, the abandoned paddy site (CTT) had the highest macrophyte coverage ( $\sim 90 \%)$, but apple snail production at this site ranked third among the four sites. The irrigation channel site (TLH) had only $\sim 5 \%$ macrophyte coverage, but apple snail production at this site ranked highest among the four sites. In addition, DO concentration did not appear to limit apple snail production. High apple snail production was maintained at the river meander site (LV) and abandoned paddy site (CTT) despite our observation that DO levels $<2 \mathrm{mg} \mathrm{l}^{-1}$ prevailed during December and January when conditions may have been inimical to other macroinvertebrates. This is consistent with observations that apple snails can rely on their lunglike pulmonary sack for aerial respiration, although their respiration may be supplemented by the ctenidium under well-oxygenated conditions (Cowie 2002). Water depth might have affected apple snail production at the pond site (NTP) where production was $<75 \%$ estimates for other populations and density and biomass were relatively low (Table 1 ). The water at NTP was relatively deep (monthly mean 0.66 vs. $0.39-0.47 \mathrm{~m}$ at other sites). Apple snails in this pond were mainly confined to the margins where macrophytes were most abundant and access to the water surface for aerial respiration was otherwise limited. Darby et al. (2002) reported that Pomacea paludosa avoids water deeper than $50 \mathrm{~cm}$ where macrophytes are absent because of the greater time and energy expenditure needed to access the surface for aerial respiration. Differences in water flow might have accounted for some of the intersite variation in apple snail production in Hong Kong, as it is notable that production in the lentic sites (paddy and pond) was lower than the lotic sites (meander and channel), and the diets of snails from lentic sites were similar to each other than diets from snails at lotic sites (see Fig. 4).

The high secondary production of $P$. canaliculata in Hong Kong indicates that it has the potential to monopolize resources, which might account for its successful establishment over the last two decades in 
almost all potentially suitable habitats in the territory (Kwong et al. 2008). Macrophytes were an important dietary component of apple snails in all 4 habitats investigated. Indeed, Pomacea spp. have been proposed as biological control agents for aquatic weeds due to their huge appetites (Cowie 2002), and high feeding rates (Boland et al. 2008); their daily feeding rate may amount to $22 \%$ of snail body weight (Qiu and Kwong 2009). We anticipate that $P$. canaliculata would have impacted the biomass and diversity of macrophytes in Hong Kong wetlands, as recently reported elsewhere in Southeast Asia (Carlsson et al. 2004; Carlsson and Lacoursière 2005). Moreover, in addition to exerting pre-emptive competition for food for other macroinvertebrates, $P$. canaliculata may prey on them. There have been reports of predation by this apple snail on freshwater bryozoans (Wood et al. 2006), adults and egg capsules of several species of pulmonates (Cazzaniga 1990; Kwong et al. 2009), as well as juveniles of $M$. tuberculata and the viviparid Sinotaia quadrata (Kwong et al. 2009). Yipp et al. (1991) reported that invasion of apple snails appeared to cause population declines in the invasive planorbid snail Biomphalaria straminea in Hong Kong, which is small and has a fragile shell and would be vulnerable to predation. Lam (1994) also noted that presence of abundant $P$. canaliculata resulted in a delayed reproduction and a longer recruitment period in another pulmonate, the lymnaeid Radix plicatulus, presumably in responses to high juvenile mortality imposed by apple snail predation.

Given the high production of $P$. canaliculata in a variety of wetlands, and the lessons learned from research on consequences arising from invasions by other freshwater molluscs (Morton 1997; Strayer 1999; Hall et al. 2006), it is necessary to assess the impact of $P$. canaliculata on biodiversity and ecosystem function in regions where it has established successfully. Research is needed on how its feeding may change macrophyte diversity, and how such changes may affect other benthic animals. More important than research in the invaded regions is the need to develop regional or national strategies that will uphold the 'precautionary principle' to prevent the spread of $P$. canaliculata and other exotic species (Lodge and Shrader-Frechette 2003; Vitule et al. 2009) into places where climate modelling predicts the potential for further invasions (Baker 1998).
Acknowledgments We thank Robert Cowie and Ken Hayes for identifying the apple snail and for providing some useful literature, and two anonymous reviewers for helpful comments on the manuscript. This study was supported by ECF/05-06/01 from Environment and Conservation Fund of Hong Kong SAR Government, and FRG/06-07/II-87 from Hong Kong Baptist University.

\section{References}

Baker GH (1998) The golden apple snail, Pomacea canaliculata (Lamarck) (Mollusca: Ampullariidae), a potential invader of fresh water habitats in Australia. In: Zalucki MP, Drew RAI, White GG (eds) Pest management-future challenges, vol 2. Proceedings of the 6th Australasian applied entomological research conference, Brisbane, 1998. University of Queensland Printery, Brisbane, pp 21-26

Benke AC (1996) Secondary production of macroinvertebrates. In: Hauer FR, Lamberti GA (eds) Methods in stream ecology. Academic Press, San Diego, pp 557-578

Boland BB, Meerhoff M, Fosalba C, Mazzeo N, Barnes MA, Burks RL (2008) Juvenile snails, adult appetites: contrasting resource consumption between two species of applesnails (Pomacea). J Molluscan Stud 74:47-54. doi: 10.1093/mollus/eym045

Bosnia AS, Kaisin FJ, Tablado A (1990) Population dynamics and production of the freshwater snail Chilina gibbosa Sowerby, 1841 (Chilinidae, Pulmonata) in a North-Patagonian reservoir. Hydrobiologia 190:97-110

Carlsson NOL, Lacoursière JO (2005) Herbivory on aquatic vascular plants by the introduced golden apple snail (Pomacea canaliculata) in Lao PDR. Biol Invasions 7:233-241. doi:10.1007/s10530-004-0741-4

Carlsson NOL, Brönmark C, Hansson LA (2004) Invading herbivory: the golden apple snail alters ecosystem functioning in Asian wetlands. Ecology 85:1575-1580. doi: 10.1890/03-3146

Cazzaniga NJ (1990) Predation of Pomacea canaliculata (Ampullariidae) on adult Biomphalaria peregrina (Planorbidae). Ann Trop Med Parasitol 84:97-100

Chatterjee A, Jain M, Roy US, Mukhopadhyay SK (2008) Limnochemical factors influencing the seasonal population density, secondary production, and calcium-to-tissue ratio in the freshwater limpet Sepratia lineata (Archaeogastropoda: Neritidae). Turk J Zool 32:245-252

Clark KR, Gorley RN (2006) PRIMER v.6: user manual/tutorial. PRIMER-E, Plymouth

Clavero M, García-Berthou E (2005) Invasive species are a leading cause of animal extinctions. Trends Ecol Evol 20:110. doi:10.1016/j.tree.2005.01.003

Cowie RH (2002) Apple snails (Ampullariidae) as agricultural pests: their biology, impacts and management. In: Baker GM (ed) Molluscs as crop pests. CABI, Wallingford, pp 145-192

Darby PC, Bennetts RE, Croop JD, Darby PLV, Kitchens WM (1999) A comparison of sampling techniques for quantifying abundance of the Florida apple snail (Pomacea paludosa Say). J Molluscan Stud 65:195-208. doi: 10.1093/mollus/65.2.195 
Darby PC, Bennetts RE, Miller SJ, Percival HF (2002) Movements of Florida apple snails in relation to water levels and drying events. Wetlands 22:489-498. doi: 10.1672/0277-5212(2002)022[0489:MOFASI]2.0.CO;2

Dudgeon D (1986) The life cycle, population dynamics and productivity of Melanoides tuberculata (Müller, 1974) (Gastropoda: Prosobranchia: Thiaridae) in Hong Kong. J Zool 208:37-53

Dudgeon D (1999) Patterns of variation in secondary production in a tropical stream. Arch Hydrobiol 144:271-281

Dudgeon D, Corlett RT (2004) The ecology and biodiversity of Hong Kong. Friends of the Country Parks, and Joint Publishing (HK) Co. Ltd., Hong Kong

Dudgeon D, Yipp MW (1985) The diets of Hong Kong freshwater gastropods. In: Morton B, Dudgeon D (eds) The malacofauna of Hong Kong and southern China, II: Proceedings of the Second International Workshop on the Malacofauna of Hong Kong and Southern China. Hong Kong. Hong Kong University Press, Hong Kong, pp 491509

Dudgeon D, Arthington AH, Gessner MO, Kawabata Z, Knowler D, Lévêque C, Naiman RJ, Prieur-Richard AH, Soto D, Stiassny MLJ, Sullivan CA (2006) Freshwater biodiversity: importance, threats, status and conservation challenges. Biol Rev Camb Philos Soc 81:163-182. doi: 10.1017/S1464793105006950

Eleutheriadis N, Lazaridou-Dimitriadou M (1995) The life cycle, population dynamics, growth and secondary production of the snail Viviparus contectus (Gastropoda: Prosobrachia) in the marshes of the river Strymonas, Serres, Macedonia, Northern Greece. Malacologia 37:4152

Eleutheriadis N, Lazaridou-Dimitriadou M (2001) The life cycle, population dynamics, growth and secondary production of Bithynia graeca (Westerlund, 1879) (Gastropoda) in Lake Kerkini, Northern Greece. J Molluscan Stud 67:319-328. doi:10.1093/mollus/67.3.319

Estebenet AL (1995) Food and feeding in Pomacea canaliculata (Gastropoda: Ampullariidae). Veliger 38:277-283

Estebenet AL, Martín PR (2002) Pomacea canaliculata (Gastropoda: Ampullariidae): life-history traits and their plasticity. Biocell 26:83-89

Gonzalez-Solis J, Ruiz X (1996) Succession and secondary production of gastropods in the Ebro Delta rice fields. Hydrobiologia 337:85-92. doi:10.1007/BF00028509

Hall RO, Likens GE, Malcom HM (2001) Trophic basis of invertebrate production in 2 streams at the Hubbard brook experimental forest. J N Am Benthol Soc 20:432-447. doi: $10.2307 / 1468040$

Hall RO, Dybdahl MF, VanderLoop MC (2006) Extremely high secondary production of introduced snails in rivers. Ecol Appl 16:1121-1131. doi:10.1890/1051-0761(2006) 016[1121:EHSPOI]2.0.CO;2

Hayes KA, Joshi RC, Thiengo SC, Cowie RH (2008) Out of South America: multiple origins of non-native apple snails in Asia. Divers Distrib 14:701-712. doi:10.1111/j.14724642.2008.00483.x

Hong Kong Observatory (2009) Extract of meteorological observations for Hong Kong. http://www.hko.gov.hk/ wxinfo/pastwx/extract.htm. Accessed on 20 Feb 2009
Huryn AD, Benke AC, Ward GM (1995) Direct and indirect effects of geology in the distribution, biomass, and production of the freshwater snail Elimia. J N Am Benthol Soc 14:519-534. doi:10.2307/1467538

Jacobsen D, Cressa C, Dudgeon D (2008) Macroinvertebrates: compostion, life histories and production. In: Dudgeon D (ed) Aquatic ecosystems: tropical stream ecology. Elsevier Science, London, UK, pp 65-105

Joshi RC, Sebastian LS (eds) (2006) Global advances in ecology and management of golden apple snails. Philippine Rice Research Institute, Nueva Ecija

Kwong KL, Wong PK, Lau SSS, Qiu JW (2008) Determinants of the distributions of apple snails two decades after their initial invasion. Malacologia 50:293-302. doi:10.4002/ 0076-2997-50.1.293

Kwong KL, Chan RKY, Qiu JW (2009) The potential of invasive snail Pomacea canaliculata as a predator of various life-stages of five species of freshwater snails. Malacologia (in press)

Lam PKS (1994) Interspecific life-history variation in Radix plicatulus (Gastropoda: Pulmonata: Lymnaeidae). J Zool (Lond) 232:435-446. doi:10.1111/j.1469-7998.1994. tb01584.x

Lodge DM, Shrader-Frechette K (2003) Non-indigenous species: ecological explanation, environmental ethics, and public policy. Conserv Biol 17:31-37. doi:10.1046/ j.1523-1739.2003.02366.x

Lowe S, Browne M, Boudjelas S, De Poorter M (2000) 100 of the world's worst invasive alien species: a selection from the Global Invasive Species Database. Invasive Species Specialist Group (ISSG), Species Survival Commission (SSC), World Conservation Union (IUCN), Switzerland, 12 pp. www.issg.org/booklet.pdf. Accessed on $20 \mathrm{Feb}$ 2009

Mantel SK, Dudgeon D (2004) Growth and production of a tropical predatory shrimp, Macrobrachium hainanensis (Palaemonidae), in two Hong Kong streams. Freshw Biol 49:1320-1336. doi:10.1111/j.1365-2427.2004.01273.x

McNeely JA (2001) The great reshuffling: human dimensions of invasive alien species. IUCN, Cambridge

Miller RR, Williams JD, Williams JE (1989) Extinctions of North American fishes during the past century. Fisheries 14:22-38. doi:10.1577/1548-8446(1989)014<0022:EONAFD $>2.0 . \mathrm{CO} ; 2$

Morton B (1997) The aquatic nuisance species problem: a global perspective and review. In: D'Itri FM (ed) Zebra mussels and other aquatic nuisance species. Ann Arbor Press, Michigan, pp 1-54

Naylor R (1996) Invasions in agriculture: assessing the cost of the golden apple snail in Asia. Ambio 25:443-448

Qiu JW, Kwong KL (2009) Effects of macrophytes on feeding and life-history traits of the invasive apple snail Pomacea canaliculata. Freshw Biol 54:1720-1730. doi:10.1111/ j.1365-2427.2009.02225.x

Richardson TD, Brown KM (1989) Secondary production of two subtropical snails. J N Am Benthol Soc 8:229-236. doi: $10.2307 / 1467326$

Richardson TD, Scheiring JF, Brown KM (1988) Secondary production of two lotic snails. J N Am Benthol Soc 7:235245. doi: $10.2307 / 1467423$ 
Sala OE, Chapin FS, Armesto JJ, Berlow E, Bloomfield J, Dirzo R, Huber-Sanwald E, Huenneke LF, Jackson RB, Kinzig A, Leemans R, Lodge DM, Mooney HA, Oesterheld M, Poff NL, Sykes MT, Walker BH, Walker M, Wall DH (2000) Global biodiversity scenarios for the year 2100. Science 287:1770-1774. doi:10.1126/science.287. 5459.1770

Strayer D (1999) Effects of alien species on freshwater mollusks in North America. J N Am Benthol Soc 18:74-98. doi: $10.2307 / 1468010$

Sugiura N, Wada T (1999) Cold tolerance of the apple snail, Pomacea canaliculata (Lamarck), collected from various locations. Kyushu Plant Prot Res 45:59-62

Vitousek PM, Mooney HA, Lubchenco J, Melillo JM (1997) Human domination of Earth's ecosystems. Science 277:494-499. doi:10.1126/science.277.5325.494

Vitule JRS, Freire CA, Simberloff D (2009) Introduction of non-native freshwater fish can certainly be bad. Fish Fish 10:98-108. doi:10.1111/j.1467-2979.2008.00312.x

Wada T, Ichinose K, Yusa Y, Sugiura N (2004) Decrease in density of the apple snail Pomacea canaliculata (Lamarck) (Gastropoda: Ampullariidae) in paddy fields after crop rotation with soybean, and its population growth during the crop season. Appl Entomol Zool (Jpn) 39:367372. doi:10.1303/aez.2004.367
Waters TF (1977) Secondary production in inland waters. Adv Ecol Res 10:91-164. doi:10.1016/S0065-2504(08) 60235-4

Wood T, Anurakpongsatorn P, Chaichana R, Mahujchariyawong J, Satapanajaru T (2006) Heavy predation on freshwater bryozoans by the golden apple snail, Pomacea canaliculata Lamarck, 1822 (Ampulariidae). Nat Hist J Chulalongkorn Univ 6:31-36

Yam RSW, Dudgeon D (2006) Production dynamics and growth of atyid shrimps (Decapoda: Cardina spp.) in 4 Hong Kong streams: the effects of site, season, and species. J N Am Benthol Soc 25:406-416. doi:10.1899/ 0887-3593(2006)25[406:PDAGOA]2.0.CO;2

Yan YJ, Liang YL, Wang HZ (2000) Annual production of Bellamya aeruginosa in Houhu Lake, Wuhan. J Lake Sci 12:68-72

Yipp MW, Cha MM, Liang XY (1991) A preliminary impact assessment of the introduction of two species of Ampullaria (Gastropoda: Ampullariidae) into Hong Kong. In: Meier-Brook C (ed) Proceedings of the tenth International Malacological Congress, Tübingen, 1989. UNITAS Malacologia, Baja, Hungary, pp 393-397 